\title{
Comparison of pasture establishment from a conventional disc drill and a prototype strip seeder drill
}

\author{
W.L. LOWTHER', W.J. FRASER', R.F. HORRELL ${ }^{2}$ and P.D. JOHNSTONE' \\ 'MAF Technology, Invermay Agricultural Centre, Mosgiel \\ ${ }^{2}$ Agricultural Engineering Institute, Lincoln
}

\begin{abstract}
Establishment of grasses and legumes drilled in spring with a prototype strip seeder drill or a conventional tripledisc drill werecomparedon two sites in the presence and absence of paraquat. On the Earnscleugh site, plant establishment in autumn, as a percentage of viable seed sown, was higher with the prototype drill than with the triple disc drill in the absence of paraquat. The application of paraquat increased establishment with the triple disc drill and differences between the drills were not consistent over species. Paraquat had no discemible effect on the competing vegetation or establishment at Ohau Downs. Establishment of birdsfoot trefoil, cocksfoot and tall fescue, but not alsike clover, was significantly higher in autumn in the prototype drill treatment. Treatment effects on standing herbage mass on both sites followed a similar trend to establishment although paraquat increased herbage mass in the prototype drill treatments on Eamscleugh, in contrast to the nonsignificant effect on establishment. The present results indicate the potential of the prototype strip seeder drill for cost effective establishment of improved pasture species in difficult environments.
\end{abstract}

Keywords direct drilling, establishment, strip seeder, luceme, tall fescue, birdsfoot trefoil, upland brome,alsikeclover,cocksfoot,paraquat, herbicide

\section{Introduction}

Increasing pasture production on low producing hill and high country soils usually relies on the introduction of improved pasture species adapted to the environmental conditions (Scott et al. 1985). This depends on the availability of reliable, cost effective establishment techniques. Aerialoversowing is anoption, particularly for legumes, where soil moisture conditions are adequate. In drier environments, direct drilling has considerable potential but in practice results have been variable.

Twomajorproblemswithdirectdrilling areimproper seed placement (Campbell et al. 1983) and inadequate control of existing vegetation (Brash 1983). Species vary in their tolerance to sowing depth (Woodman et al. 1991) and correct sowing depth can be critical for species with low seedling vigour (Campbell 1985; Chapmanetal. 1990). Controlofdepthofseedplacement is particularly difficult on areas with rough terrain typical of those in the tussock grasslands. In dry environments, herbicide control of competing vegetation is usually necessary to reduce competition for moisture during the first summer (Douglas 1985). However, the high cost of herbicide application reduces the cost effectiveness of direct drilling and in some instances herbicides can be ineffective in controlling weeds such as sorrel (Rumex acetosella L.) in early spring before drilling (Brash 1983). Mechanical control of competing vegetation has been obtained using a rotodrill (Dunbar et of. 1980). However lack of mechanical reliability, particularly in areas with rocks, has limited the potential of these type of drills.

A prototype strip seeder drill has been developed as a cost effective, robust and mechanically sound singlepass direcıdrill. Emphasishasbeenplacedonmechanical reduction of competing vegetation and control of depth of sowing even in rough environments. Details of the mechanical specifications and design of the MAF/AEI prototype drill have been given by Horrell $e t$ al. (1992). Agronomic data on the establishment of grasses and legumes following overdrilling into two sites, representative of depleted, dry tussock grasslands, are presented in this paper.

\section{Materials and Methods}

The experiment compared the establishment of 4pasture species (2 legumes and 2 grasses) after drilling with a conventional triple disc or the MAF/AEI prototype strip seeder in the presence and absence of herbicide application. A split plot trial design was used with 2 (drill) x 4 (species) main plots and 2 (herbicide) subplots and 4 replicate blocks.

Trials were laid down in Central Otago and the Mackenzie Country. The Central Otago site was on Eamscleugh Station on a Conroy sandy loam (BGE) at an altitude of $600 \mathrm{~m}$ with a mean annual rainfall of 
approximately $340 \mathrm{~mm}$ and $\mathrm{pH}$ 5.9. The area had previously been oversown and topdressed but a combination of lack of maintenance fertiliser, and high rabbit populations had resulted in a very depleted vegetative cover of scabweed (Raoulia spp.), hairgrass (Vulpia bromoides L.), fescue tussock (Festuca novaezelandiae L.), and broadleaf weeds. The Mackenzie site was on Ohau Downs Station on an Ohau silt loam (YBE) at an altitude of $550 \mathrm{~m}$ with a mean annual rainfall of approximately $510 \mathrm{~mm}$ and $\mathrm{pH}$ 5.7.The site was undeveloped and had been subject to an extensive grazing regime. The dominant vegetative cover consisted of fescue tussock, hawkweed (Hieracium pilosella L.), sorrel, browntop (Agrostis capillaris L.), and a native plant understorey.

The pasture species were drilled with either a conventional triple disc drill or prototype strip seeder drill. Mechanical details are given by Horrell et al. (1992). The species used (Table 1) were thoseconsidered to be suited to the different sites. Due to possible problems with inoculationofbirdsfoot trefoil (Chapman $\boldsymbol{e t}$ al. 1990) all legume seed was inoculated at 5 times the manufacturers stipulated rate with the incorporation of $10 \%$ gum arabic in the slurry and sown within 1 day of inoculation. All grass seed was coated by the Superstrike process. Each pasture species plotconsistedof one $54 \mathrm{~m}$ long drillrun (width $2.25 \mathrm{~m}$ ) of 15 coulters with the triple disc drill and 10 coulters with the MAF/AEI prototype drill. Seedingrates were calculatedon aperhectarebasis and therefore were sown 50\% higher within each coulter row with the MAF/AEI prototype drill than with the triple disc drill.

Table 1 Plant species sown at each site (kg per ha).

\begin{tabular}{llcc}
\hline SPECIES & & EARNSCLEUGH & OHAU DOWNS \\
\hline G 32 birdsfoot trefoil & (Lotus corniculatus L.) & 6 & 6 \\
Otaio Iucerne & (Medicago sativa L.) & 10 & nil' \\
Tetra alsike clover & (Trifolium hybridum L.) & nil & 6 \\
Wana cocksfoot & (Dactylis giomerata L.) & 10 & 10 \\
Cajun tall fescue & (Festuca arundinacea L.) & 18 & nil \\
Hakari upland brome & (Bromus margina tus L.) & nil & 25 \\
\hline
\end{tabular}

Not drilled at site.

Table 2 Comparison of a prototype drill and a disc drill on the establishment (as a of seed sown) at the end of Spring (October) and Summer (May).

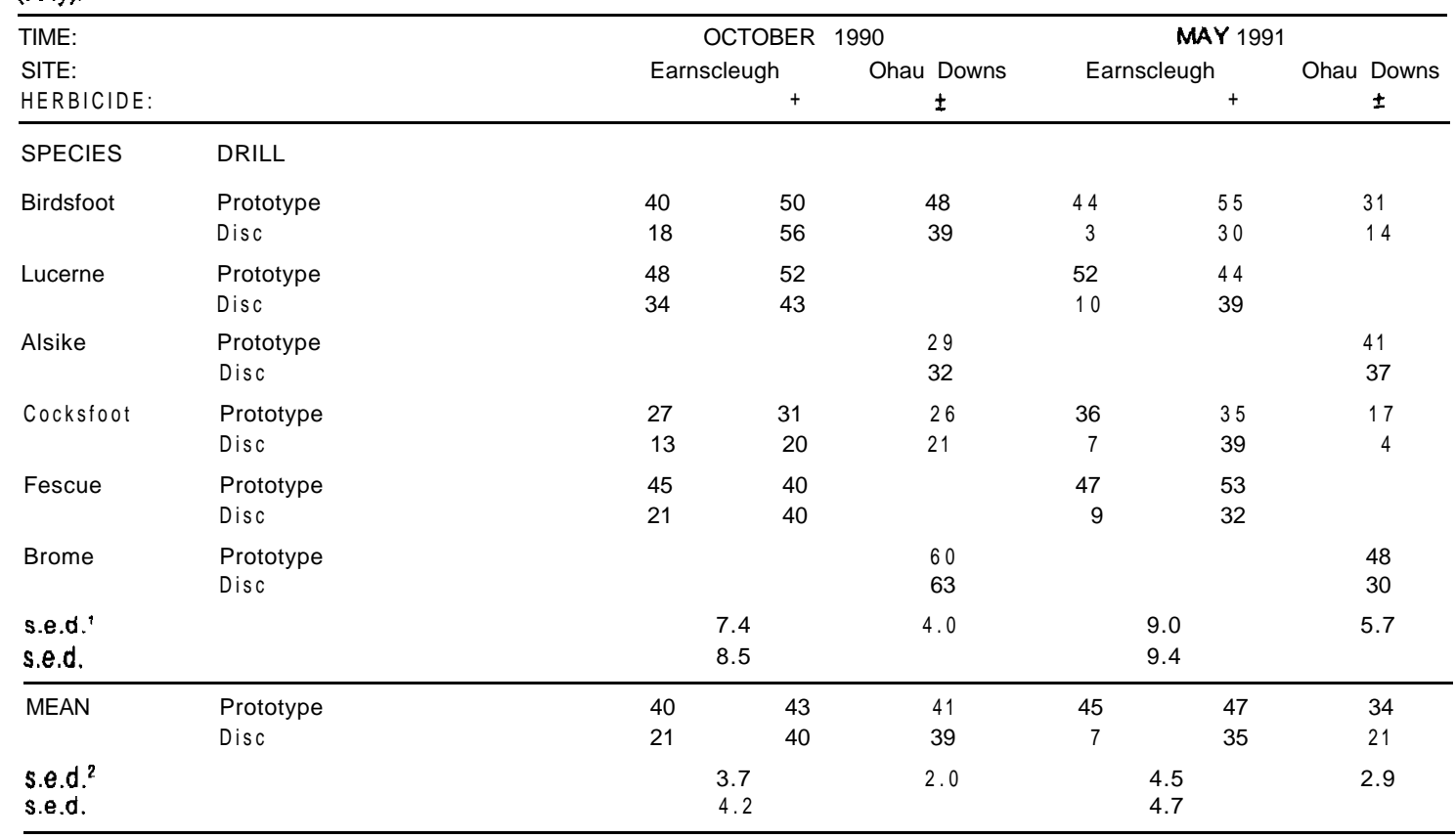

Except when comparing means with the same level(s) of SPECIES.DRILL.

Except when comparing means with the same level(s) of DRILL. 
Half of eachdrilling plot was sprayed with paraquat at $0.6 \mathrm{~kg}$ ai/ha 3-7 days before sowing.

Fertiliser was applied by drill through a separate box at the rate equivalent to $100 \mathrm{~kg} / \mathrm{ha}$ maxi-sulphursuperphosphate $(50 \% \mathrm{~S}, 5 \% \mathrm{P})$ at Earnscleugh and 250 $\mathrm{kg} / \mathrm{ha}$ superphosphate $(12 \% \mathrm{~S}, 9 \% \mathrm{P})$ at Ohau Downs. Molybdenum at $50 \mathrm{~g} / \mathrm{ha}$ was sprayed on to the plots and Miral $5 \mathrm{G}$ insecticide $(50 \mathrm{~g} / \mathrm{kg}$ isazophos) at $40 \mathrm{~kg} / \mathrm{ha}$ was broadcast after sowing. The Eamscleugh site $\mathrm{w}$ as drilled on 11 September 1990 and Ohau Downs was drilled on 30 August 1990.

Establishment was recorded by counting seedlings in spring (October) and then in autumn (May) and expressing as percentage of viable seed sown. Herbage mass was assessed by cutting to ground level in January and May (Eamscleugh) and May (Ohau Downs) and expressing as DM sown species per hectare. Presented yield information has been back-transformed after analysis of log data by analysis of variance.

\section{Results}

\section{Seedling establishment}

At the October assessment on the Eamscleugh site, there was a significant $(p<0.05)$ interaction on seedling establishment between drill type and herbicide treatment (Table 2). Seedling establishment in all species was higher from the prototype strip seeder than from the disc drill in the absence of herbicide. Paraquat application significantly increased seedling establishment with the disc drill, resulting in little difference between drills in the presence of herbicide.

Herbicide application had no apparent effect on the existing vegetation or on establishment on the Ohau Downs site and hence results from the herbicide comparisons have been combined. In October, there was no significant difference in seedling establishment between the two drills.

On Eamscleugh Station, few seedlings survived over summer in the triple disc treatment in the absence of paraquat (Table 2). This contrasts with the survival in the prototype drill treatments in both presence and absence of paraquat. Plant numbers in autumn were higher from the prototype drill than from the disc drill in the absence of paraquat. However, in the presence of paraquat, the difference between drills was apparent only with birdsfoot trefoil and tall fescue. The application of paraquat increased establishment of all species in the triple disc treatment.

At Ohau Downs, birdsfoot trefoil, cocksfoot and upland bromeplant numbers in autumn were significantly higher in the prototype drill than in the triple disc drill.

\section{Growth}

Standing herbage mass of sown species at Eamscleugh Station was higher from the prototype drill than the disc drill in both the absence and presence of herbicide (Table 3). However, paraquat application increased yield with both drills.

On the Ohau Downs site, there was insufficient grass growth to harvest. The standing herbagemass of birdsfoot trefoil was significantly higher in the prototype drill than in triple disc drill treatment.

Table 3 Comparison of a prototype drill and a disc drill on standing herbage mass of sown species ( $\mathrm{kg} \mathrm{DM} / \mathrm{ha}$ ), means are given with 95 \% confidence intervals bracketed beneath.

\begin{tabular}{|c|c|c|c|c|}
\hline \multirow{3}{*}{$\begin{array}{l}\text { TIME: J } \\
\text { SITE: } \\
\text { HERBICIDE } \\
\text { SPECIES: }\end{array}$} & \multirow{2}{*}{\multicolumn{2}{|c|}{$\begin{array}{c}\text { JANUARY } 1990+\text { MAY } 1991 \\
\text { Earnscleugh }\end{array}$}} & \multicolumn{2}{|c|}{ MAY 1991} \\
\hline & & & Ohau & Downs \\
\hline & E & + & Birdsfoot & Alsike \\
\hline Prototype & $\begin{array}{c}417 \\
(260-668)\end{array}$ & $\begin{array}{c}860 \\
(536-1 \quad 380)\end{array}$ & $\begin{array}{c}162 \\
(86-307)\end{array}$ & $\begin{array}{c}247 \\
(131-467)\end{array}$ \\
\hline Disc & $\begin{array}{c}33 \\
(20-53)\end{array}$ & $\begin{array}{c}307 \\
(191-493)\end{array}$ & $\begin{array}{c}48 \\
(25-91)\end{array}$ & $\begin{array}{c}334 \\
(177-631)\end{array}$ \\
\hline
\end{tabular}

\section{Discussion}

Results presented by Horrell et al. (1992) indicate clearly that the prototype drill effectively removed a furrow of existing vegetation. The results from Eamscleugh confirm that this mechanical removal of vegetation effectively reduced competition for moisture for the establishing plants. This reduction in competition was evident on both early seedling establishment and plant survival in autumn. The response in herbage mass in the prototype drill plots to the paraquat treatment is not unexpected as the prototype removed only a $10 \mathrm{~cm}$ wide slot of turf. Plants growing in the row can have been expected to experience competition for moisture from the roots of the vegetation growing between the rows. However, the most important feature of the prototype drill was that similar numbers of plants survived in the presence and absence of herbicide.

One of the stated aims of the development project was to improve seedling germination by precision depth control of seeding, a factor implicated in poor seedling establishment from conventional disc drills (Campbell et al. 1983). Problems were encountered in controlling seed depth in this prototype and in general all species were sown below the optimum depth (Horrell $\boldsymbol{e}$ t al. 1992). Further development of the prototype drill is underway to improve seed placement depth. 
At Earnscleugh there was an interaction between drill type and herbicide. However, at Ohau Downs there was no apparent effect from herbicide on establishment or growth from either drill. This is attributed to a lack of effect of herbicide on the existing vegetation. Paraquat was used rather than glyphosate because it was expected to be more effective on the short vegetation present in early spring. Brash (1983) commented on the lack of effect of glyphosate applied in spring, particularly in controlling sorrel, and recommended further research into defining the most appropriate herbicide material, rate and timing in these environments. In contrast, paraquat was effective on Eamscleugh where perennials such as sorrel and Hieracium were virtually absent from the vegetation cover.

The present results confirm the potential of the MAF/AEI prototype strip seeder for establishing legumes and grasses in low producing tussock grassland environments. Figures calculated by Horrell $\boldsymbol{e t}$ al. (1992) indicate savings of between $\$ 53$ and $\$ 88$ per hectare are achievable by sowing pasture with a strip seeder rather than a disc drill with herbicide. These savings are important in attempting to develop cost effective development strategies for the low producing semi-arid grasslands of the hill and high country of the South Island.

\section{ACKNOWLEDGEMENTS}

The authors wish to thank RichardDoney, Kevin Trainor and Robert Woodman for assistance in establishing and managing trials, and data collection. Also Alistair Campbell, John Blue and Hamish Brown for providing the trial sites.

\section{REFERENCES}

Brash, D.W. 1983. Dryland luceme establishment by overdrilling in Central Otago. Proceedings of the NZ Grassland Association 44: 164-169.

Campbell, B.D. 1985. Winged coulter depth effects on overdrilled red clover seedling emergence. NZ journal of agricultural research 28: 7-17.

Campbell, B.D.; Cosgrove, G.P.; Harris, W. 1983. Why overdrilling red clover in Manawatu lowland failed. Proceedings of the NZ Grassland Association 44: 156-163.

Chapman, H.M.; Lowther, W.L.; Trainor, K.D. 1990. Some factors limiting the success of Lotus corniculatus in hill and high country. Proceedings of the NZ Grassland Association 51:147-150.

Dunbar, G.A.; Horrell, R.F.; Costello, E.J. 1980. Gverdrilling of dry hill country. Proceedings of the Lincoln College Farmers Conference 29: 372-383.

Horrell, R.F.; Lowther, W.L.; Keoghan, J.M. 1992. Development of low cost overdrilling technology for pasture establishment. Proceedings of the NZ Grassland Association 53: 5 l-54.

Scott, D.; Keoghan, J.M; Cossens, G.G.; Maunsell, L.A.; Floate, M.J.S.; Wills,B.J.; Douglas, G. 1985. Limitations to pasture production and choice of species. In Burgess, R.E.; Brock, J.L. (Eds.). Using herbage cultivars. Grasslands Research and Practice Series No. 3 NZ Grassland Association : 9-15.

Woodman, R.F.; Doney, R.J.; Allan, B.E. 1990. Effects of drilling depth on seedling growth of seven dryland pasture species. Proceedings of the NZ Grassland Association 52: 167-170. 